Received $\quad 18.01 .2018$

Reviewed 13.04 .2018

Accepted 21.05.2018

A - study design

B - data collection

C - statistical analysis

D - data interpretation

$\mathbf{E}$ - manuscript preparation

F - literature search

\section{Mathematical modelling of filtration processes in drainage systems using conformal mapping}

\footnotetext{
1) Rivne State University of Humanities, Faculty of Mathematics and Informatics, Rivne, Ukraine; e-mail: abomba@ukr.net; Im_vova@ukr.net

2) National University of Water and Environmental Engineering, Institute of Water Management and Environmental Engineering, Soborna St, 11, Rivne, Rivnens'ka oblast, Ukraine, 33028; e-mail: m.m.tkachuk@nuwm.edu.ua; r.o.kyrysha@nuwm.edu.ua; e.g.gerasimov@nuwm.edu.ua; o.1.pinchuk@nuwm.edu.ua
}

For citation: Bomba A., Tkachuk M., Havryliuk V., Kyrysha R., Gerasimov I., Pinchuk O. 2018. Mathematical modelling of filtration processes in drainage systems using conformal mapping. Journal of Water and Land Development. No. 39 p. 11-15. DOI: $10.2478 /$ jwld-2018-0054.

\begin{abstract}
The situation when groundwater considerably rises above the "normal" level, water intake, lowering of groundwater levels and other relevant practical tasks require the drainage facilities. The most effective techniques of numerical studies of the corresponding boundary problems at present time are methods of dealing with inverse boundary value problems (conformal and quasi-conformal mappings). As basis of this research we used the case of combining the fictitious domain methods with quasi-conformal mappings of the solution of nonlinear boundary value problems for the calculation of filtration regimes in environments with free boundary areas (depression curves) and zones of "mountainous" areas.

This paper reviews the stationary issue of flat-vertical stationary non-pressure liquid filtration to horizontal symmetric drainage. In the paper a practical methodology for solving boundary value problems on conformal mappings is suggested for the calculation of the filtration process in the horizontal symmetrical drainage.

The idea of block iterative methods was used during the creation of the corresponding algorithm which is based on the alternating "freeze" of the anticipated conformance parameter, the internal and boundary connections of the curvilinear area.

The results of the conducted numerical calculations confirmed the effectiveness of the suggested problem formulations and algorithms of their numerical solution and the possibility of their use in the modelling of nonlinear filtration processes occurring in horizontal drainage systems, as well as in the design of drainage facilities and optimizing other hydrosystems. Therefore these results are of great importance.
\end{abstract}

Key words: conformal mapping, drainage systems, filtration processes, flood protection, mathematical modelling

\section{INTRODUCTION}

Groundwater flood protection of territories and municipalities, when groundwater considerably rises above the "normal" level, water intake and lowering of groundwater levels, as well as other relevant practical tasks, are all associated with the need for drainage facilities. This issue is especially important for amelioration, where drainage is the key element of any amelioration system [MARTYNYUK 2015; ROKOCHINSKIY et al. 2017; SMEDEMA 2011]. Nowadays, the methods of dealing with inverse boundary value problems (conformal and quasi-conformal mappings) are the most effective techniques of numerical studies of the corresponding boundary problems [BERESLAVSKII, LIKHA- 
CHEVA 2011; CARABINEANU 2015; ORLOV et al. 2016]. In particular, the previous studies [BOMBA et al. 2007a] examine the case of combining the fictitious domain methods and quasi-conformal mappings of the solution of nonlinear boundary value problems for the calculation of filtration regimes in environments with free boundary areas (depression curves) and zones of ,mountainous” areas. At the same time, the other study [BOMBA et al. 2008] suggests an algorithm for a numerical solution of model nonlinear boundary value problems through quasi-conformal mappings in the areas bounded by two equipotential lines and two flow lines, when one of the boundary fragments is an unknown (free) curve with fixed and free ends. This paper reviews the stationary issue of flat-vertical stationary nonpressure liquid filtration to horizontal symmetric drainage.

\section{MATERIALS AND METHODS}

Statement of problem. Let's consider the process of filtration to horizontal drainage. Due to the symmetry of the flow pattern, we shall study only one fragment of such a system, namely a single-connected hexagonal curvilinear area (porous layer) $\partial G_{z}=A B C^{*} C_{*} C D(z=x+i y$ ) (see Fig. 1) limited by two lines of the current

$$
\begin{gathered}
A D=\left\{z: x=0,-h_{1}+r \leq y \leq 0\right\} \\
B C^{*}=\left\{z: x=l,-h_{1}-r-h_{2} \leq y \leq 0\right\} \\
C_{*} C^{*}=\left\{z: y=-h_{1}-r-h_{2}, 0 \leq x \leq l\right\} \\
C C_{*}=\left\{z: x=0,-h_{1}-r-h_{2} \leq y \leq-h_{1}-r\right\}
\end{gathered}
$$

as well as two equipotential lines

$$
C D=\left\{z: x-\sqrt{r^{2}-\left(y+h_{1}\right)^{2}}=0,-h_{1}-r \leq y \leq-h_{1}+r\right\}
$$$$
\text { and } A B=\{z: y=0,0 \leq x \leq l\}
$$

Similarly as BOMBA et al. [2007b; 2008], we shall describe it by the flow equation $\vec{v}=k \operatorname{grad} \varphi$ (Darcy's law) and continuity equation $\operatorname{div} \vec{v}=0$, where $\vec{v}=\left[v_{x}(x, y)+\mathrm{i} v_{y}(x, y)\right]$ is the filtration rate, $k$ is the coefficient of conductivity, piecewise constant in the area $G_{z}$, so that it is $k=k_{1}$ at $\left(-h_{1}<y \leq h_{1}+0.3\right)$ and $\left(x<=t_{f}\right),(x, y) \in G_{z}, k=k_{2}$ whenever $\left(-h_{1}<y \leq h_{1}+0.3\right)$ and $\left(t_{f}<=x<=b_{t p}\right),(x, y) \in G_{z}$, while for the rest of the area $G_{z}-k=k_{3}$. The classical conjugation conditions are used at the boundary of the section [BOMBA et al. 2007b] $\varphi=\varphi(x, y)$ is potential at the point $(x, y)$, so that $\left.\varphi\right|_{A B}=0$ (is equal to the pressure on the horizon), $\left.\varphi\right|_{C D}=\varphi^{*}\left(h_{1}\right)=h_{1}$ (the average value of the pressure in the drain, which is equal to the depth of its laying), $\left.\frac{\partial \varphi}{\partial \vec{n}}\right|_{B C^{*} C_{*} C}=\left.\frac{\partial \varphi}{\partial \vec{n}}\right|_{A D}=0, \vec{n}$ is the outward normal on the corresponding range of the area boundary.

The conforming problem, if it is viewed through conformal mapping $\omega=\omega(z)=\varphi(x, y)+\mathrm{i} \psi(x, y)$ of the considered area $G_{z}$ to the corresponding sector of the complex potential $G_{\omega}=\left\{\omega: \varphi_{*}<\varphi<h_{1}, 0<\psi<Q\right\}$ with unknown discharge $Q$ shall look as follows [BOMBA et al. 2007a, 2008]:

$$
\begin{gathered}
k \frac{\partial \varphi}{\partial x}=\frac{\partial \psi}{\partial y}, \quad k \frac{\partial \varphi}{\partial y}=-\frac{\partial \psi}{\partial y} \\
\left.\varphi\right|_{A B}=0,\left.\quad \varphi\right|_{C D}=h_{1},\left.\quad \psi\right|_{A D}=0,\left.\quad \psi\right|_{B C^{*} C_{*} C}=Q
\end{gathered}
$$

The inverse problem of equations (1) - (2) on the conformal mapping $z=z(\omega)=x(\varphi, \psi)+\mathrm{i} y(\varphi, \psi)$ in the area $G_{\omega}$ at $G_{z}$ with unknown discharge $Q$ shall be presented as:

$$
\begin{aligned}
& \left\{\begin{array}{c}
k \frac{\partial y}{\partial \psi}=\frac{\partial x}{\partial \varphi} \\
k \frac{\partial x}{\partial \psi}=-\frac{\partial y}{\partial \varphi}
\end{array}(\varphi, \psi) \in G_{\omega}\right. \\
& \left\{\begin{aligned}
y\left(\varphi_{*}, \psi\right)=0, & 0 \leq \psi \leq Q \\
x\left(h_{1}, \psi\right)-\sqrt{r^{2}-\left(y\left(h_{1}, \psi\right)+h_{1}\right)}=0, & 0 \leq \psi \leq Q \\
x(\varphi, Q)=l, & 0 \leq \varphi \leq \varphi_{1} \\
y(\varphi, Q)=-h_{1}-r-h_{2}, & \varphi_{1} \leq \varphi \leq \varphi_{2} \\
x(\varphi, Q)=0, & \varphi_{2} \leq \varphi \leq h_{1} \\
x(\varphi, 0)=0, & 0 \leq \varphi \leq h_{1} \\
g(y(\varphi, \psi))=\varphi, & 0 \leq \psi \leq Q, 0 \leq \varphi \leq h_{1}
\end{aligned}\right.
\end{aligned}
$$

The corresponding second order equations used in order to find functions $x=x(\varphi, \psi)$ and $y=y(\varphi, \psi)$ in a divergent form shall look as follows:

$$
\begin{aligned}
& \frac{\partial}{\partial \varphi}\left(\frac{1}{k} \frac{\partial x}{\partial \varphi}\right)+\frac{\partial}{\partial \psi}\left(k \frac{\partial x}{\partial \psi}\right)=0 \\
& \frac{\partial}{\partial \varphi}\left(\frac{1}{k} \frac{\partial y}{\partial \varphi}\right)+\frac{\partial}{\partial \psi}\left(k \frac{\partial y}{\partial \psi}\right)=0
\end{aligned}
$$

Algorithm for numerical solution of the problem. The difference analogue of equations (5), boundary conditions (4), near-boundary orthogonality conditions and conditions of so-called "conformal similarity in the small" of the corresponding quadrilaterals, in the relevant uniform grid area

b)

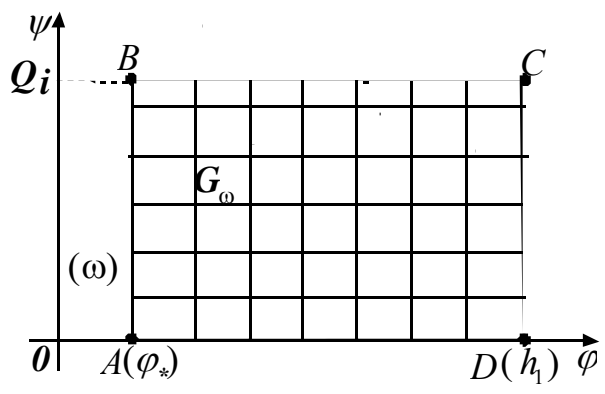

Fig. 1. Filtration area $G_{z}$ (a) and corresponding complex potential area $G_{\omega}(\mathrm{b})$; source: own elaboration 
$G_{\omega}^{\gamma}=\left\{\left(\varphi_{i}, \psi_{j}\right): \varphi_{i}=\Delta \varphi \cdot i, i=\overline{0, m+1} ; \psi_{j}=\Delta \psi \cdot j, j=\overline{0, n+1} ; \Delta \varphi=\frac{h_{1}}{m+1}, \Delta \psi=\frac{Q}{n+1}, \gamma=\frac{\Delta \varphi}{\Delta \psi}, m, m_{1}, m_{2}, n \in \mathrm{N}\right\}$ we shall write as follows [BOMBA et al. 2008; MARCHUK 1980; SAMARSKIY 1977]:

$$
\begin{aligned}
& \left\{\begin{aligned}
y_{0, j}=0, & j=\overline{0, n+1} \\
x_{m+1, j}-\sqrt{r^{2}-\left(y_{m+1, j}+h_{1}\right)}=0, & j=\overline{0, n+1} \\
x_{i, n+1}=l, & i=\overline{0, m_{1}} \\
y_{i, n+1}=-h_{1}-r-h_{2}, & i=\overline{m_{1}, m_{2}} \\
x_{i, n+1}=0, & i=\overline{m_{2}, m+1} \\
x_{i, 0}=0, & i=\overline{0, m+1}
\end{aligned}\right. \\
& \left\{\begin{array}{c}
\sigma\left[a_{i+1, j+1} x_{i+1, j+1}-\left(a_{i+1, j+1}+a_{i, j+1}\right) x_{i, j+1}+a_{i, j+1} x_{i-1, j+1}\right]+ \\
+(1-2 \sigma)\left[a_{i+1, j} x_{i+1, j}-\left(a_{i+1, j}+a_{i, j}\right) x_{i, j}+a_{i, j} x_{i-1, j}\right]+ \\
+\sigma\left[a_{i+1, j-1} x_{i+1, j-1}-\left(a_{i+1, j-1}+a_{i, j-1}\right) x_{i, j-1}+a_{i, j-1} x_{i-1, j-1}\right]+ \\
+\gamma^{2}\left\{\sigma\left[b_{i+1, j+1} x_{i+1, j+1}-\left(b_{i+1, j+1}+b_{i+1, j}\right) x_{i+1, j}+b_{i+1, j} x_{i+1, j-1}\right]+\right. \\
+(1-2 \sigma)\left[b_{i, j+1} x_{i, j+1}-\left(b_{i, j+1}+b_{i, j}\right) x_{i, j}+b_{i, j} x_{i, j-1}\right]+ \\
\left.+\sigma\left[b_{i-1, j+1} x_{i-1, j+1}-\left(b_{i-1, j+1}+b_{i-1, j}\right) x_{i-1, j}+b_{i-1, j} x_{i-1, j-1}\right]\right\}=0 \\
\sigma\left[a_{i+1, j+1} y_{i+1, j+1}-\left(a_{i+1, j+1}+a_{i, j+1}\right) y_{i, j+1}+a_{i, j+1} y_{i-1, j+1}\right]+ \\
+(1-2 \sigma)\left[a_{i+1, j} y_{i+1, j}-\left(a_{i+1, j}+a_{i, j}\right) y_{i, j}+a_{i, j} y_{i-1, j}\right]+ \\
+\sigma\left[a_{i+1, j-1} y_{i+1, j-1}-\left(a_{i+1, j-1}+a_{i, j-1}\right) y_{i, j-1}+a_{i, j-1} y_{i-1, j-1}\right]+ \\
+\gamma^{2}\left\{\sigma\left[b_{i+1, j+1} y_{i+1, j+1}-\left(b_{i+1, j+1}+b_{i+1, j}\right) y_{i+1, j}+b_{i+1, j} y_{i+1, j-1}\right]+\right. \\
+(1-2 \sigma)\left[b_{i, j+1} y_{i, j+1}-\left(b_{i, j+1}+b_{i, j}\right) y_{i, j}+b_{i, j} y_{i, j-1}\right]+ \\
\left.+\sigma\left[b_{i-1, j+1} y_{i-1, j+1}-\left(b_{i-1, j+1}+b_{i-1, j}\right) y_{i-1, j}+b_{i-1, j} y_{i-1, j-1}\right]\right\}=0 \\
i=\overline{1, m}, j=\overline{1, n}
\end{array}\right. \\
& \left\{\begin{aligned}
\left(x_{1, j}-x_{0, j}\right) & =0, \quad j=\overline{0, n+1} \\
\sqrt{r^{2}-\left(y_{m+1, j}\right)}\left(y_{m, j}-y_{m+1, j}\right)-\left(y_{m+1, j}+h_{1}\right)\left(x_{m, j}-x_{m+1, j}\right) & =0, \quad j=\overline{0, n+1} \\
\left(y_{1, n}-y_{i, n+1}\right) & =0, \quad i=\overline{0, m_{1}} \\
\left(x_{i, n}-x_{i, n+1}\right) & =0, \quad i=\overline{m_{1}, m_{2}} \\
\left(y_{i, n}-y_{i, n+1}\right) & =0, \quad i=\overline{m_{2}, m+1} \\
\left(y_{i, 1}-y_{i, 0}\right) & =0, \quad i=\overline{0, m+1}
\end{aligned}\right. \\
& \gamma=\frac{1}{(m+1)(n+1} \sum_{i, j=0}^{m, n} \frac{1}{k_{i+\frac{1}{2}, j+\frac{1}{2}}} \gamma_{i, j} \\
& \gamma_{i, j}=\frac{\sqrt{\left(x_{i+1, j}-x_{i, j}\right)^{2}+\left(y_{i+1, j}-y_{i, j}\right)^{2}}+\sqrt{\left(x_{i+1, j+1}-x_{i, j+1}\right)^{2}+\left(y_{i+1, j+1}-y_{i, j+1}\right)^{2}}}{\sqrt{\left(x_{i, j+1}-x_{i, j}\right)^{2}+\left(y_{i, j+1}-y_{i, j}\right)^{2}}+\sqrt{\left(x_{i+1, j+1}-x_{i+1, j}\right)^{2}+\left(y_{i+1, j+1}-y_{i+1, j}\right)^{2}}}
\end{aligned}
$$

where: $a_{i, j}=2 /\left(k_{i, j}+k_{i-1, j}\right), b_{i, j}=\left(k_{i, j-1}+k_{i, j}\right) / 2, x_{i, j}=x\left(\varphi_{i}, \psi_{j}\right)$, $y_{i, j}=y\left(\varphi_{i}, \psi_{j}\right), k_{i+1 / 2, j+1 / 2}=\left(k_{i, j}+k_{i+1, j}+k_{i, j+1}+k_{i+1, j+1}\right) / 4$, $\sigma \in[0,0.5]$ are weighting factors.

The solution of the difference problem (6) - (9) should be presented as [BOMBA et al. 2007b: 2008]. We set the number of $m$ and $n$ joint connections of the grid area $G_{\omega}$ partition, parameter $\varepsilon$ which characterises the approximation accuracy of the corresponding difference problem solution. We set the initial approximation of the set of values. Namely: the initial approximation of the coordinates of the boundary connections $x_{0, j}^{(0)}, y_{0, j}^{(0)}, x_{m+1, j}^{(0)}, y_{m+1, j}^{(0)}, x_{i, n+1}^{(0)}$, $y_{i, n+1}^{(0)}, x_{i, 0}^{(0)}, y_{i, 0}^{(0)}$ (so that it satisfies the equalities set in the equation (7), as well as the initial approximation of the coordinates of the internal connections $\left(x_{i, j}^{(0)}, y_{i, j}^{(0)}\right)$, $i=\overline{1, m}, j=\overline{1, n}$. We shall set the initial approximation of a conformal invariant $\gamma$ according to the Equation (9) which uses the newly set initial values of the coordinates of the internal connections, i.e. $\gamma^{(0)}=\gamma\left(x_{i, j}^{(0)}, y_{i, j}^{(0)}\right)$. Then we make a refinement of the following: the internal con- 
nections $\left(x_{i, j}^{(k+1)}, y_{i, j}^{(k+1)}\right)(\mathrm{k}=0,1, \ldots)$ is the number of the iteration step) using the Gauss-Seidel method according to the formulas obtained by solving the equation (6) with respect to $x_{i, j}$ and $y_{i, j} ; \gamma$ value according to the Equation (9), the coordinates of the boundary connections, for instance, by solving the system of nonlinear equations (7) and (8). Subsequently, we check if all terms of finishing the computational process are satisfied, for example, in line with the following equations:

$$
\begin{gathered}
\max _{x_{i, j}, y_{i, j} \in \partial G_{z}}\left(\left|x_{i, j}^{(k+1)}-x_{i, j}^{(k)}\right|,\left|y_{i, j}^{(k+1)}-y_{i, j}^{(k)}\right|\right)<\varepsilon \\
\left|Q^{(k+1)}-Q^{(k)}\right|<\varepsilon,\left|D^{(k+1)}-D^{(k)}\right|<\varepsilon,
\end{gathered}
$$

where

$$
D=\frac{1}{(m+1)(n+1)} \sum_{i, j=0}^{m, n} \frac{\sqrt{\left(x_{i+1, j+1}-x_{i, j}\right)^{2}+\left(y_{i+1, j+1}-y_{i, j}\right)^{2}}}{\sqrt{\left(x_{i, j+1}-x_{i+1, j}\right)^{2}+\left(y_{i, j+1}-y_{i+1, j}\right)^{2}}}
$$

is the average value of the ratio of the lengths of the diagonals of the curvilinear quadrilaterals of the grid area $G_{z}^{\gamma}$.

If the conditions set in (11) are not satisfied, then we come back to the step of the refinement of the internal connections and so on. In the opposite case, we calculate the closure error of the resulting grid conformance according to the equation $\varepsilon_{*}^{*}=|1-D|$. Its value characterises the deviation of the resulting curvilinear quadrilaterals from the corresponding rectangles (since the ratio of the lengths of the diagonals in a rectangle is equal to one, and the existence of right angles is the fundamental orthogonality condition).

In case if, for instance, only one of the conditions (11) is not satisfied, we reconcile the relationship between accuracy $\varepsilon *$ and the given number of partition steps $m, n$ (first of all, by increasing the latter ones). If, however, we need to improve of accuracy of the approximate solution (to reduce the closure error $\varepsilon^{*}$ ), we increase the parameters of the partition $m$ and $n$ and solve the difference problem (6) - (9) again. The optimality of the relationship between $m$ and $n$ is achieved analogously to BoMBA et al. [2007b; 2008] by optimising the functional analogues of Riemann integral. The argumentation of the created algorithm for „step-by-step recording of the process and environment (medium) characteristics, conformance parameter, internal and boundary joint connections of the curvilinear area" shall be carried out analogously to BOMBA et al. [2007b; 2008] using the ideas of block iterative methods.

\section{RESULTS AND DISCUSSION}

After doing calculations according to the described algorithm with the following numerical values: total filter thickness $l=3 \mathrm{~m}$, depth of drainage laying $h_{1}=0.675 \mathrm{~m}$, drain radius $r=0.025 \mathrm{~m}$, distance from drainage to impenetrable basis $C_{*} C^{*} h_{2}=1.3 \mathrm{~m}$, thickness of one layer of filter $t_{f}=0.01 \mathrm{~m}$, thickness of two layers of filter $b_{t p}=0.05$ $\mathrm{m}$, partition $m n=30 \times 16$ of the $G_{z}$ area, accuracy of approximation $\varepsilon=10^{-5}$, conductivity coefficients of the medium $k_{1}=50 \mathrm{~m} \cdot$ day $^{-1}, k_{2}=10 \mathrm{~m} \cdot$ day $^{-1}, k_{3}=1 \mathrm{~m} \cdot$ day $^{-1}$ for $k=2847$ steps, we shall obtain a hydrodynamic motion grid (see Fig. 1a), velocity field, we shall also find the total seepage discharge $Q=1.065 \mathrm{~m} \cdot$ day $^{-1}$ and other process characteristics.

Particularly, Table 1 demonstrates the results of numerical calculations of the seepage discharge depending on the change of $k_{1}, k_{2}, k_{3}, t_{f}, b_{t p}$ parameters.

Table 1. Results of numerical calculations of the seepage discharge $Q$ depending on the change of $k_{1}, k_{2}, k_{3}, t_{f}, b_{t p}$ parameters

\begin{tabular}{|l|l|l|l|l|l|}
\hline$k_{1}$ & $k_{2}$ & $k_{3}$ & $t_{f}$ & $b_{t p}$ & \multicolumn{1}{|c|}{$Q$} \\
\hline 50 & 10 & 1 & 0.01 & 0.05 & 0.920320260082948 \\
\hline 50 & 12 & 1 & 0.01 & 0.05 & 0.960873665785776 \\
\hline 50 & 14 & 1 & 0.01 & 0.05 & 0.987617056663534 \\
\hline 50 & 16 & 1 & 0.01 & 0.05 & 1.00835392085078 \\
\hline 50 & 18 & 1 & 0.01 & 0.05 & 1.03851097519713 \\
\hline 50 & 20 & 1 & 0.01 & 0.05 & 1.06577163362688 \\
\hline 50 & 22 & 1 & 0.01 & 0.05 & 1.10114973682152 \\
\hline 40 & 10 & 1 & 0.01 & 0.05 & 0.896314526530931 \\
\hline 45 & 10 & 1 & 0.01 & 0.05 & 0.902018405768276 \\
\hline 50 & 10 & 1 & 0.01 & 0.05 & 0.920320260082948 \\
\hline 55 & 10 & 1 & 0.01 & 0.05 & 0.927833093747881 \\
\hline 60 & 10 & 1 & 0.01 & 0.05 & 0.943876562915457 \\
\hline 65 & 10 & 1 & 0.01 & 0.05 & 0.948026524377088 \\
\hline 70 & 10 & 1 & 0.01 & 0.05 & 0.950105136285527 \\
\hline 50 & 20 & 1 & 0.01 & 0.05 & 1.06577163362688 \\
\hline 50 & 20 & 1 & 0.015 & 0.05 & 1.02366903997431 \\
\hline 50 & 20 & 1 & 0.02 & 0.05 & 0.952081581579486 \\
\hline 50 & 20 & 1 & 0.025 & 0.05 & 0.946986240371109 \\
\hline 50 & 20 & 1 & 0.01 & 0.035 & 1.04081701488922 \\
\hline 50 & 20 & 1 & 0.01 & 0.04 & 1.04539368741735 \\
\hline 50 & 20 & 1 & 0.01 & 0.045 & 1.05341165619218 \\
\hline 50 & 20 & 1 & 0.01 & 0.05 & 1.06577163362688 \\
\hline
\end{tabular}

Explanations: $k_{1}, k_{2}, k_{3}=$ conductivity coefficients of the medium, $t_{f}=$ thickness of one layer of filter, $b_{t p}=$ thickness of two layers of filter. Source: own study.

\section{CONCLUSIONS}

Therefore, the paper suggests a practical methodology for solving boundary value problems on conformal mappings for the calculation of the filtration process in the horizontal symmetrical drainage.

During the argumentation (as well as construction) of the corresponding algorithm which is based on the alternating ,freeze" of the anticipated conformance parameter, the internal and boundary connections of the curvilinear area etc., we have used the ideas of block iterative methods [MARCHUK 1980].

The results of the conducted numerical calculations confirmed the effectiveness of the suggested problem formulations and algorithms of their numerical solution and the possibility of their use in the modelling of nonlinear filtration processes occurring in horizontal drainage systems, as well as in the design of drainage facilities and optimising other hydrotechnical systems, and, hence, the paper results are hugely valuable.

\section{REFERENCES}

Bereslavskit E.N., LiKhacheVA N.V. 2011. Mathematical modeling of filtration from canals and sprinklers of irrigation systems. Applied Mathematics. Vol. 1. No. 2 p. 122-129. DOI 10.5923/j.am.20110102.20. 
Bomba A.Ya., Bulavatsky V.M., SKOPETSKYI V.V. 2007a. Neliniini matematychni modeli protsesiv heohidrodynamiky [Nonlinear mathematical models of geohydrodynamic processes]. Kyiv. Naukova dumka. ISBN 978-966-00-0652-2 pp. 308.

Bomba A.Ya., HavryliuK V.I. 2008. Modyfikatsiia alhorytmu chyslovoho rozviazannia obernenykh zadach na kvazikonformni vidobrazhennia dlia vypadku oblastei $\mathrm{z}$ vilnymy mezhamy [Modification of the algorithm for numerical solution of inverse problems on quasi-conformal mappings for areas with free boundaries]. Visnyk Kharkivskoho natsional'noho universytetu. Ser. Matematychne modeliuvannia. Informatsiini tekhnolohii. Avtomatyzovani systemy upravlinnia. No. 833 p. 39-46.

Bomba A.Ya., Havryliuk V.I., SkopetskiY V.V. 2007b. Novaya metodika resheniya nelineynykh kraevykh zadach so svobodnymi granitsami i vklyucheniyami [New method for solving nonlinear boundary value problems with free bounds and inclusions]. Kompyuternaya matematika. No. 1 p. 31-39.

CARABINEANU A. 2015. A conformal mapping approach for investigating the free-boundary seepage from symmetric channels. Complex Variables and Elliptic Equations: An International Journal. Vol. 60. Iss. 9 p. 1190-1204. DOI 10.1080/ 17476933.2014.1002400.
MARCHUK G. I. 1989. Metody vychislitelnoy matematiki [Methods of computational mathematics]. Kiev. Naukova dumka. ISBN 5-02-014222-0 pp. 608.

MARTYNYUK P. M. 2015. Existence and uniqueness of a solution of the problem with free boundary in the theory of filtration consolidation of soils with regard for the influence of technogenic factors. Journal of Mathematical Sciences. Vol. 207. Iss. 1 p. 59-73. DOI 10.1007/s10958-015-2355-z.

Orlov V., SAFONYK A., MARTYNOV S., KunYtSkyi S. 2016. Simulation the process of iron removal the underground water by polystyrene foam filters. International Journal of Pure and Applied Mathematics. Vol. 109. No. 4 p. 881-888. DOI 10.12732/ijpam.v109i4.11.

RokochinskiY A., Volk P., Pinchuk O., Mendus S., Koptyuk R. 2017. Comparative evaluation of various approaches to the foundation of parameters of agricultural drainage. Journal of Water and Land Development. No. 34 p. 215-220. DOI 10.1515/jwld-2017-0056.

SAMARSKIY A. A. 1977. Teoriya raznostnykh skhem [The theory of difference schemes]. Moscow. Nauka pp. 656.

Smedema L. K. 2011. Drainage development: Driving forces, conducive conditions and development trajectories. Irrigation and Drainage. Vol. 60. Iss. 5 p. 654-659. DOI 10.1002/ird. 615 .

\section{Andrii BOMBA, Mykola TKACHUK, Volodymyr HAVRYLIUK, Ruslan KYRYSHA, Ievgenii GERASIMOV, Oleg PINCHUK}

\section{Matematyczne modelowanie procesów filtracji w systemach drenarskich z zastosowaniem odwzorowania konforemnego}

\section{STRESZCZENIE}

W przypadku podwyższenia poziomu wody gruntowej znacząco ponad „normalną” wysokość pobór wody, obniżanie jej zwierciadła i inne działania wymagają urządzeń drenarskich. Obecnie najbardziej efektywnymi technikami numerycznych badań odpowiednich problemów brzegowych są metody odwrotnej analizy wartości brzegowych (odwzorowania konforemne i quasi-konforemne). Jako podstawę prowadzonych badań przyjęto przykład połączenia metod fikcyjnej domeny z quasi-konforemnym odwzorowaniem rozwiązania problemu nieliniowych wartości brzegowych do obliczenia reżimu filtracji w środowisku o wolnej powierzchni brzegowej (krzywe depresji) i w strefach ,górskich”.

W pracy dokonano przeglądu rozwiązań pionowej stacjonarnej filtracji płynów do horyzontalnego symetrycznego drenażu. Zaproponowano praktyczną metodologię rozwiązywania problemów wartości brzegowych w przekształceniu konforemnym do obliczania procesu filtracji w horyzontalnym symetrycznym drenażu.

Wykorzystano zasadę metod iteracyjnych podczas tworzenia odpowiednich algorytmów opartą na naprzemiennym „zamrażaniu” przewidywanego parametru odwzorowania z wewnętrznymi i brzegowymi powiązaniami krzywoliniowego obszaru.

Wyniki przeprowadzonych numerycznych obliczeń potwierdzają efektywność formułowania sugerowanego problemu i algorytmów ich numerycznego rozwiązania oraz możliwości ich zastosowania w modelowaniu nieliniowych procesów filtracji występujących w horyzontalnym systemie odwadniania, w projektowaniu urządzeń drenarskich i w optymalizacji innych systemów wodnych. Z tego powodu uzyskane wyniki mają ogromne znaczenie.

Słowa kluczowe: modelowanie matematyczne, ochrona przeciwpowodziowa, odwzorowanie konforemne, procesy filtracji, systemy drenarskie 